Article

\title{
Agricultural Cooperatives and COVID-19 in Southeast Africa. The Role of Managerial Capital for Rural Resilience
}

\author{
Nicola Francesconi ${ }^{1, *}$, Fleur Wouterse ${ }^{2}$ and Dorothy Birungi Namuyiga ${ }^{3,4}(\mathbb{C}$ \\ 1 Royal Tropical Institute (KIT), 1092 Amsterdam, The Netherlands \\ 2 Global Center on Adaptation (GCA), 3072 Rotterdam, The Netherlands; fleur.wouterse@gca.org \\ 3 Center for Development Research (ZEF), 53113 Bonn, Germany; dbirungi8@gmail.com \\ 4 National Agricultural Research Organization (NARO), 295 Entebbe, Uganda \\ * Correspondence: francesconi@edc.coop
}

check for updates

Citation: Francesconi, N.; Wouterse, F.; Birungi Namuyiga, D. Agricultural Cooperatives and COVID-19 in Southeast Africa. The Role of Managerial Capital for Rural Resilience. Sustainability 2021, 13, 1046. https://doi.org/10.3390/ su13031046

Received: 5 October 2020

Accepted: 14 January 2021

Published: 20 January 2021

Publisher's Note: MDPI stays neutral with regard to jurisdictional claims in published maps and institutional affiliations.

Copyright: (c) 2021 by the authors. Licensee MDPI, Basel, Switzerland. This article is an open access article distributed under the terms and conditions of the Creative Commons Attribution (CC BY) license (https:// creativecommons.org/licenses/by/ $4.0 /)$.

\begin{abstract}
While the health impact of COVID-19 in most African countries appears modest, the impact of social distancing measures, closing of markets and reduced mobility is felt across the board. Domestic, labor-intensive and traditional food value chains and the smallholders they serve appear to be particularly affected. During a systemic shock where idiosyncratic risk coping strategies fail, collective or organizational resilience becomes of the essence to protect the livelihoods of smallholders. In this study, we have used pre- and during-shock data on agricultural cooperatives from Southeast Africa to understand how resilient these smallholder-owned organizations are. We find that many organizations could not countervail market-disruptions and fell into a state of dormancy during the pandemic. One reason for this is that collective decision-making was heavily affected by the banning of gatherings. Only a few organizations devised innovative solutions to maintain the market linkages of rural smallholders. The lack of resilience demonstrated by most cooperatives appears to be associated with organizational immaturity, large membership size, elite capture and limited business-orientation, which underscore a general lack of managerial capital.
\end{abstract}

Keywords: rural smallholders; agricultural cooperatives; COVID-19; Africa

\section{Introduction}

Even if the number of COVID-19 infections reported from Africa remains relatively low, concerns are growing about how the pandemic will affect the continent's already fragile food systems. Social distancing measures enforced by African governments during this public health crisis are affecting domestic, labor-intensive and traditional food value chains more than international, capital-intensive and modern food value chains. In many African countries, home confinement or reduced mobility and transportation have disrupted domestic food production, for example, by preventing households from traveling to their plots, mobilizing sufficient labor or obtaining inputs. Similar measures were imposed during the recent Ebola outbreak in West Africa and these disrupted labor mobilization for farming and harvesting and reduced the area planted as well as yields [1]. The marketing of agriculture produce, which typically involves a myriad of small- and medium-sized transactions has also been affected by the COVID-19 outbreak. Output marketing tends to be a contact-intensive process with farmers using public transport to travel to crowded marketplaces. For example, domestic vegetable markets in Ethiopia, which rely on poorly developed infrastructure and traditional distribution networks, have been affected by interruptions in transport and in the distribution of inputs during the initial phase of the COVID-19 pandemic. In sharp contrast, international food supply chains appear to have held up reasonably well even in countries with strict social distancing rules. International food value chains have the advantage of being highly integrated and automated, thereby requiring minimal human interactions [2]. Additionally, governments worldwide have placed high priority on avoiding disruptions of international food value chains. 
African governments also have a history of cracking down on domestic and traditional markets, especially during public health crises [3]. When the Zambian government used the military to close down informal markets during the cholera outbreak in 2018, farmers lost a significant amount of income and many slid into poverty. Since much of the continent's population depends on traditional markets for food, lockdowns and other social distancing measures can exacerbate food insecurity especially among a rapidly growing class of poor urban consumers [3]. During the food crisis of 2007-2008, mass and sometimes violent unrest erupted in several African cities and this could reoccur if prolonged or repeated market disruptions cause another spike in the price of staple foods [3]. The ongoing COVID-19 crisis could also increase Africa's dependency on imported food, widen the gap between African and international agribusiness development and further aggravate global inequality and migration. This crisis thus represents a critical juncture for the pursuit of reforms and innovations to consolidate and streamline traditional food value chains within Africa.

Farm households throughout Africa have long since organized to reduce exposure to idiosyncratic risk, which accounts for most of the shocks affecting agriculture-dependent livelihoods [4-6]. The scant data available suggest that every other rural village in Africa houses a smallholder-owned cooperative organization of some sort [7-16]. The proliferation of such organizations is largely attributed to a wealth of social capital that results from interdependent rural livelihoods $[17,18]$. Although these organizations continue to serve important social protection functions in many African countries, their role in countervailing market failures that plague the business operations of smallholders has been generally negligible [19-25]. A persistent lack of managerial capital and the rapid rise of market competition are said to have hindered the integration of smallholder-owned organizations in emerging agri-food value chains [20].

The COVID-19 pandemic and the related economic outfall constitute a systemic shock that cannot be mitigated by resorting to idiosyncratic risk-coping strategies. The social distancing measures imposed to control the pandemic have left smallholders unable to access markets and have further eroded their income-generating capacity and self-reliance. The urgency for rural cooperative organizations to help their smallholder-members access markets and facilitate their value chain integration is thus more pressing than ever. However, given the complexity of the COVID-19 crisis, the organizational change required to do so is likely to be risky and disruptive. To our knowledge, the question that remains unanswered is whether rural and smallholder-owned organizations are able to manage this change and alleviate the effect of such a systemic shock. In this study, we contribute to filling this gap in the literature using pre- and during-shock data collected from the leaders of farmer-owned organizations in Southeast Africa. We find that these organizations have come up with innovative solutions to mitigate some of the impacts of the pandemic but that these attempts are constrained by a general lack of managerial capital. Because these traditional and labor-intensive organizations are heavily affected by the crisis and to sustain an already fragile domestic food system, governments would do well to factor in farmerowned organizations in their COVID-19 response. Efforts to build the managerial capital of rural communities can, for example, involve the recruitment or professionalization of business-managers as well as the digitization of internal and external communication.

\section{History and Theory of Collective Action in Rural Africa}

In precolonial Africa, farm-households were traditionally organized into autarkic communities based on kinship and hierarchical principles [26,27]. The idiosyncratic risks associated with subsistence farming were usually shared within a community through mutual support and revolving or rotating schemes [28]. These community-based schemes were intended to facilitate the exchange of labor, food and other resources among community members in times of need. Well documented examples include: the "tontine" (rotating saving and insurance schemes) in Senegal, "greniers villageois" (or community-based grain banks) in Burkina Faso and Niger, "idir" (funeral societies) and "iqub" (saving and insurance clubs) in Ethiopia, and "nnoboa" (mutual help groups) and "susu" (rotating savings, 
credit and insurance schemes) in Ghana. Although these community-based organizations or associations continue to be widespread and serve important social protection functions in many African countries, their contribution to agricultural trade and rural incomes has been rather negligible [29,30].

To address this shortcoming, colonial administrations took over the management of many community-based organizations by the end of the nineteenth century. Colonialism brought significant change to rural communities as subsistence farming was replaced by strategies to develop commercial plantations for cash crops (such as rubber, coffee, cocoa, tea, etc.). These strategies involved the institutionalization of village-based organizations into formal cooperative enterprises to promote agricultural production for export without disrupting the pre-existing social structure. However, the top-down nature of these cooperatives transformed agricultural communities into subsidiary organizations of colonial trading companies. After independence, many of the newly established African governments centralized the management of colonial cooperatives, which de-facto became subsidiaries of parastatal firms and mere channels for the distribution of agricultural output and inputs, subsidies and services [8-13,16,20-22,25,30].

In the late 1980s, growing international pressure for structural adjustment reforms led to the withdrawal of government from economic functions and the dismantling of parastatal companies. These reforms created an institutional vacuum that led to the collapse of most state-led cooperatives and a return to traditional and community-based organizations. However, a general lack of managerial capital at the level of rural communities coupled with a rapid rise of global competition-in the form of food imports and private agricultural estates-have hindered the integration of farmer-owned organizations in emerging markets. With the exception of some notable but isolated success stories, rural collective action has remained largely dependent on government support. The marginalization of African smallholders from increasingly globalized markets is also associated with mounting aid and development efforts. Yet, governments and donors have tended to focus on the provision of support packages, economic incentives and subsidies but have overlooked the managerial capital deficit that affects the competitiveness of farmer-owned organizations. This oversight can be partly attributed to the paradigmatic boundaries that have historically and geographically separated agricultural production processes from management theory as well as to the propensity of donors and governments to favor direct financial assistance over capacity building and organizational strengthening [8-11,16,19-22,31]. To sum up, the history of collective action in rural Africa thus involved the rise of community-based organizations, their take-over by the colonial administration and parastatals and the ultimate loosening of governmental control and regeneration.

In the context of rural Africa, community-based organizations (as depicted by the bottom-up pyramid on the right hand side of Figure 1) and colonial or parastatal firms (as depicted by the top-down pyramid on the left hand size of Figure 1) have so far prevailed over cooperative enterprises (as depicted by the two pyramids at the center of Figure 1). The importance of managerial capital as a mean to sustain collective action has long been recognized. [32-34] were among the first to recognize that unless a group is small, collective action requires substantial management capacity. More recently, $[35,36]$ demonstrate that managerial capital constitutes the missing link between small and medium sized enterprises and markets and suggest that the pervasive business failure in developing countries can be attributed to a general lack of managerial capital. In line with this, the conceptual framework in Figure 1 postulates that managerial capital is the missing element in the evolution of contemporary community-organizations into fully-fledged cooperative enterprises. The rise of cooperatives that combine social and managerial capital is especially important to ensure rural resilience in the face of idiosyncratic as well as systemic shocks. 


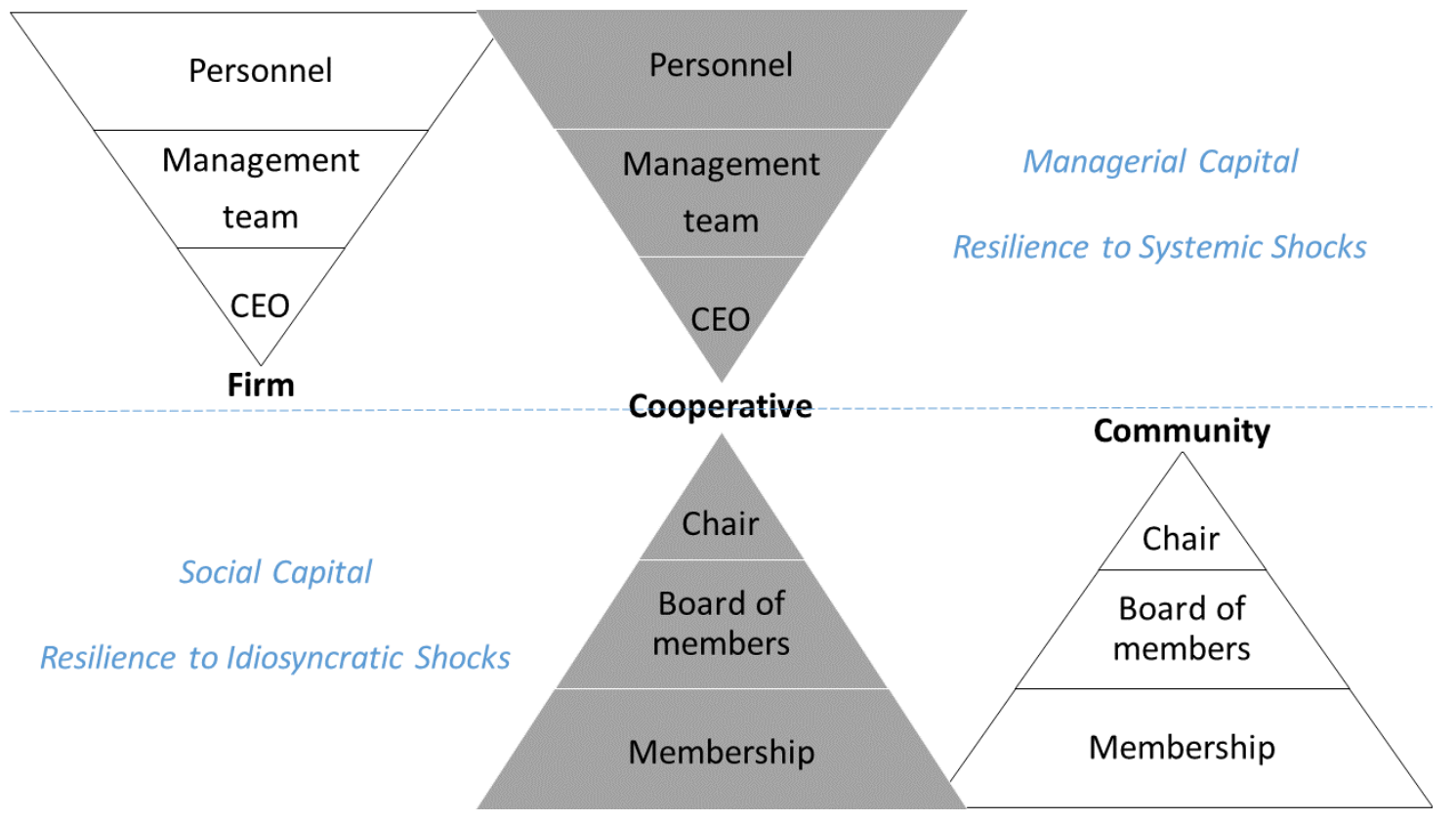

Figure 1. Conceptual framework.

While idiosyncratic shocks can be managed or mitigated through the mobilization of external and mutual support, systemic or economy-wide shocks require collective adaptation and organizational change or innovation. [37] argues that the comparative advantage of cooperative enterprises is the greater resilience of these organizations in comparison to firms. This advantage is said to explain the unparalleled longevity demonstrated by agricultural cooperatives in the U.S. many of which are almost 100 years old. In the presence of a systemic shock, like the one induced by the COVID-19 pandemic, the survival of community-based organizations in rural Africa as well as their ability to bounce back may thus depend on their capacity to build up managerial capital and develop into fully-fledged cooperative enterprises. As the COVID-19 crisis further erodes the income-generating capacity and self-reliance of rural smallholders, their organizations are urged to overcome social distancing measures by internalizing and professionalizing management over smallholders' input and output transactions.

\section{Data Descriptives from before COVID-19}

The pre-COVID data used in this study were collected during five Cooperative Learning and Leadership Events (CLLEs) that took place between 2016 and 2019 in Uganda, Malawi, Madagascar, Rwanda and Kenya. These events were organized by the U.S. Overseas Cooperative Development Council (OCDC), in collaboration with CTA (EU-ACP), CIAT (CGIAR) and multiple international and in-country partners (Including OXFAM, NCBA-CLUSA, GIZ, FAO, IFAD, Land O'Lakes, USADF, Global Communities, HealthPartners, Genex, ACE (Malawi), ACDI-VOCA, NASFAM (Malawi), FUM (Malawi), UCA (Uganda), UNFFE (Uganda), NCCR (Rwanda), CUK (Kenya)). The CLLEs were intended to strengthen the cooperative management practices of rural leaders and their stakeholders and collect primary data on farmer-owned organizations. First, in-country partners selected these organizations on the basis of a stratified sampling techniques striving towards country-level representativeness. Second, each organization chose one leader (or board member) to participate in a given CLLE. (All participants received full sponsorship, over a period of five days per participant, by the organizers of these events). Third, at least a week before the event, selected organizations received a structured and standardized survey to fill out. Responses were revisited during the CLLEs through extensive focus group discussions facilitated by research-assistants under the direct supervision of the authors of this study. This event-based survey methodology allowed for the reduction in 
information asymmetries between respondents and researchers and produced quantitative data for a total of 443 farmer-owned organizations from the five target countries and a wealth of context relevant-information.

As described in Table 1, the 443 organizations in our dataset cover all regions and 64 percent of districts in the five countries. Coverage is inevitably smaller in Madagascarthe largest country-and larger in Rwanda-the smallest country. Kenya has a significantly smaller sample than the other countries because the last CLLE held in Nairobi gathered the leaders of several organizations that were not involved in agriculture and were therefore discarded from this analysis. It is important to note that no major shocks-such as droughts, floods, pests, economic recessions, wars, epidemics, etc.- - had occurred in any of the five countries during the 12 months that preceded and encompassed data collection.

Table 1. Sample of farmer-owned organizations from south-east Africa (pre-COVID).

\begin{tabular}{cccc}
\hline Country (Survey Date) & Sampled Regions & Sampled Districts & Sampled Organizations \\
\hline Uganda (May 2016) & $100 \%$ & $50 \%$ & 96 \\
Malawi (September 2016) & $100 \%$ & $86 \%$ & 92 \\
Madagascar (February 2017) & $100 \%$ & $35 \%$ & 104 \\
Rwanda (February 2018) & $100 \%$ & $90 \%$ & 97 \\
Kenya (August 2019) & $100 \%$ & $57 \%$ & 54 \\
All countries & $100 \%$ & $64 \%$ & 443 \\
\hline
\end{tabular}

Source: Authors' computation based on survey data. ${ }^{1}$ (The new constitution of Kenya, adopted in 2013, replaced previously existing regions (known as provinces) and sub-regional districts by a system of 47 counties. For the purpose of this cross-country comparison, Table 1 refers to the former regions of Kenya and considers its 47 counties as if they were districts).

In what follows, the available data is described with the intention to assess the status of farmer-owned organizations under pre-COVID circumstances. In particular, we compute the age, business-membership ratio, managerial resources and membership size of sampled organizations and assess their potential resilience during the pandemic. The average longevity of sampled organizations can be considered as a proxy of their resilience [37]. Table 2 shows that the average organization is approximately nine years old and therefore quite young. The age of these organizations varies substantially across and within countries, ranging from one to 69 years, with Kenyan organizations standing out for being the oldest (23 years old on average) and Malagasy organizations for being the youngest (three years old on average). We would thus expect Kenyan and Malagasy organizations to be respectively the most and least resilient during the COVID-19 crisis.

Table 2. Longevity/maturity of farmer-owned organizations.

\begin{tabular}{cccc}
\hline Age of Organizations: & Obs. & Mean (Std. Dev.) & Min/Max \\
\hline Uganda (in years since establishment) & 96 & $9.8(13.1)$ & $1 / 63$ \\
Malawi (in years since establishment) & 92 & $6.7(5.9)$ & $1 / 29$ \\
Madagascar (in years since establishment) & 104 & $3.2(3.5)$ & $1 / 18$ \\
Rwanda (in years since establishment) & 97 & $9.9(5.4)$ & $1 / 42$ \\
Kenya (in years since establishment) & 54 & $23.2(22.4)$ & $1 / 69$ \\
All countries (in years since establishment) & 443 & $9.2(12.1)$ & $1 / 69$ \\
\hline
\end{tabular}

Source: Authors' computation based on survey data.

A second proxy-indicator of organizational resilience is the business-membership ratio or the annual revenues that an organization generates per member through commercializaion of agricultural produce. Organizations that pursue defensive strategies-as opposed to commercial or business-oriented strategies-are expected to be less resilient as they prioritize service provision over income generation $[37,38]$. Table 3 shows that the average business-membership ratio is estimated at just 115 USD per member per year corresponding to a daily revenue of about 0.30 USD per member. In contrast, agricultural cooperatives in Europe are estimated to commercialize 40-50 percent of the surplus produced by domestic farmers on an annual basis [39]. Again, the income generation capacity 
of farmer-owned organizations varies across and within countries. Annual per capita revenues range from zero to almost 2000 USD and are notably higher in Rwanda (215 USD) and Kenya (201 USD) compared to Madagascar (76 USD), Uganda (64 USD) and Malawi (55 USD). Based on this indicator we would expect Rwandan and Kenyan organizations to be the most likely to show some resilience during the COVID-19 crisis.

Table 3. Income-generation capacity of farmer-owned organizations.

\begin{tabular}{cccc}
\hline Business-Membership Ratio: $^{2}$ & Obs. & Mean (Std. Dev.) & Min/Max \\
\hline Uganda (USD/year) & 96 & $64.3(178.1)$ & $0 / 1167$ \\
Malawi (USD/year) & 92 & $54.7(143.1)$ & $0 / 1087$ \\
Madagascar (USD/year) & 104 & $75.9(164.4)$ & $0 / 809$ \\
Rwanda (USD/year) & 97 & $215.2(303.5)$ & $0 / 1208$ \\
Kenya (USD/year) & 54 & $200.9(369.9)$ & $0 / 1920$ \\
All countries (USD/year) & 446 & $114.8(242.5)$ & $0 / 1920$ \\
\hline
\end{tabular}

Source: Authors' computation based on survey data. ${ }^{2}$ (The business-membership ratio $(Y)$ is defined as the revenues generated by an organization $i$ over the previous 12 months through the aggregation and commercialisation of members' agricultural produce $(B)$, divided by the number of registered members $\left.(M): Y_{i}=B_{i} / M_{i}\right)$.

According to $[35,36]$ pervasive agribusiness failure among SMEs in the context of developing countries is attributable to a general lack of managerial capital. Figure 2 shows that only five percent of sampled organizations employed professional managers at the time of the survey. Here, a professional manager is a CEO or director who receives a salary from his/her organization of at least 500 USD per month. In contrast, most agricultural cooperatives in Europe do have a professional manager [40]. Again, there is some variation between countries and the percentage of organizations employing professional managers is higher in Kenya (18 percent) and Rwanda (8 percent) and zero in Madagascar.

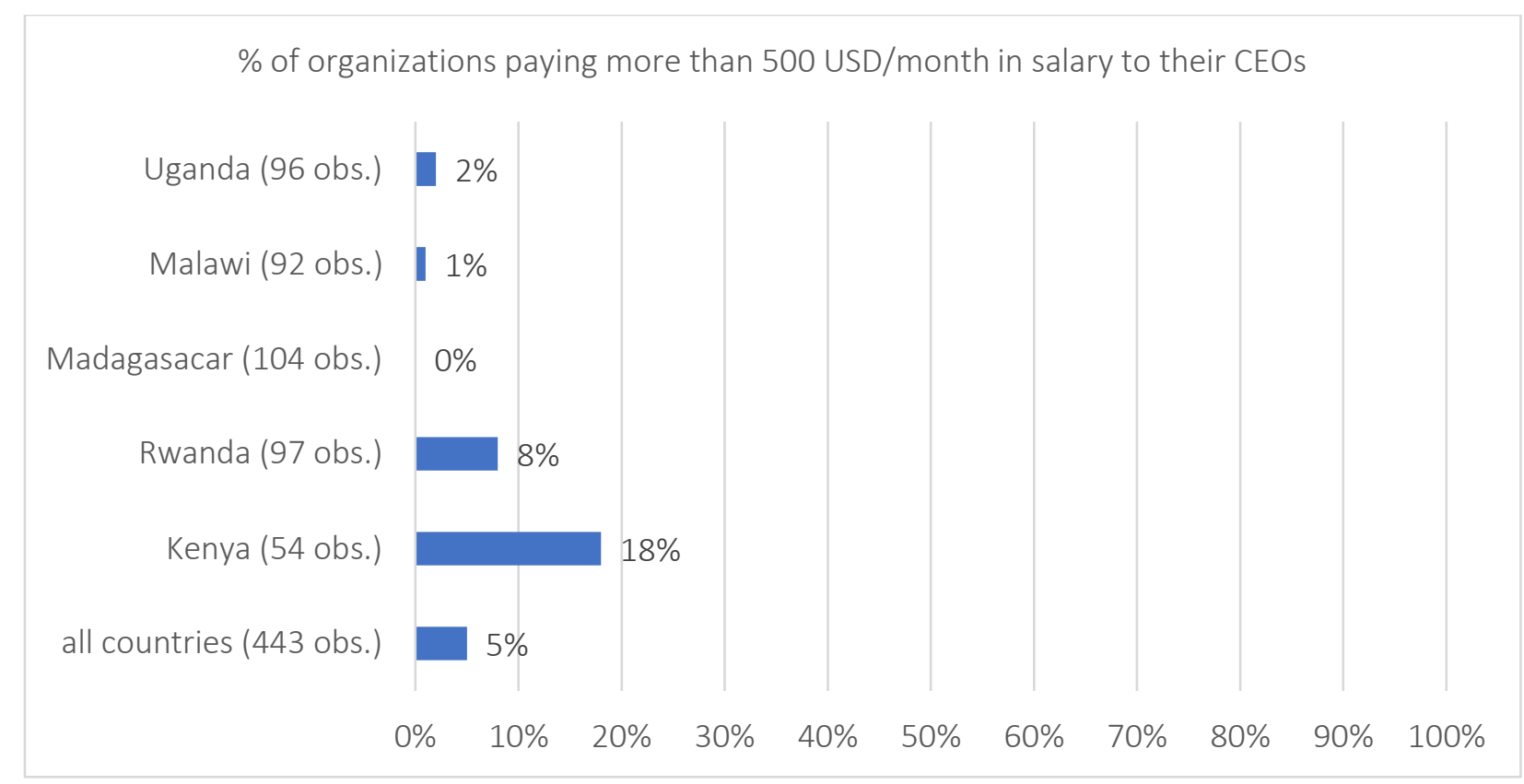

Figure 2. Prevalence of farmer-owned organizations with professional managers. Source: Authors' computation based on survey data.

In the absence of professional managers, farmer-owned organizations are usually managed by rural and traditional leaders, which tend to be men $[17,27]$. This means that efforts to strengthen the managerial capital of rural leaders are unlikely to ensure genderequity in the running of farmer-owned organizations nor social inclusion. Figure 3 shows that only about a third of organizations selected female leaders to participate in the CLLEs and benefit from related management training. Again, variation between countries exists 
and in Rwanda half of the rural leaders that received managerial training were women. In contrast, the CLLE held in Kenya involved only 16 percent of female trainees. In line with previous findings, we would thus expect Malawian, Malagasy and Ugandan organizationswhich are the least likely to have either professional management or female leadership-to be less resilient during the COVID-19 crisis.

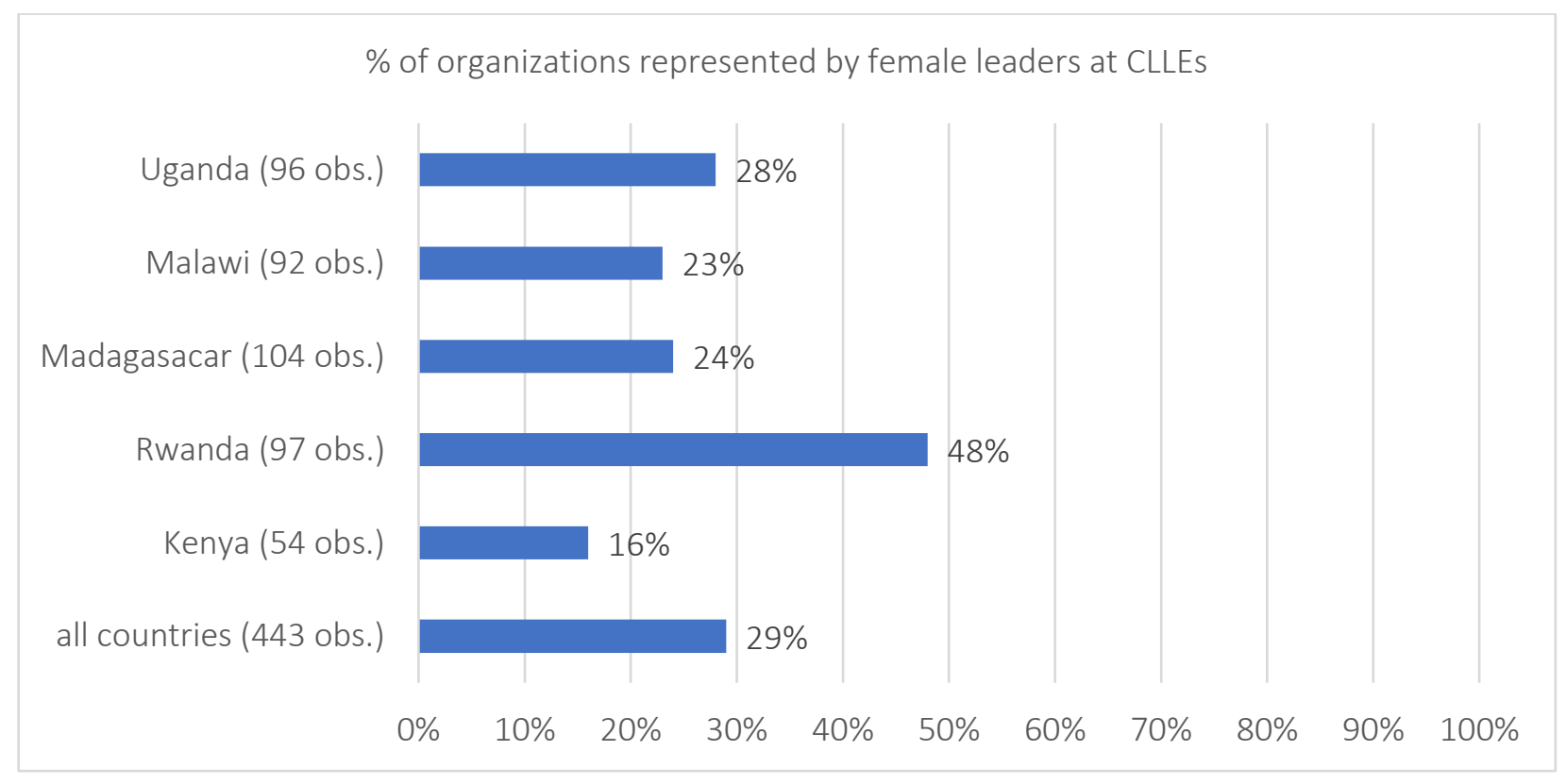

Figure 3. Prevalence of farmer-owned organizations with female-leaders. Source: Authors' computation based on survey data.

Unless a group is small, collective action requires substantial management capacity [32-34]. The importance of managerial capital in farmer-owned organizations is thus expected to increase in parallel with membership size. Table 4 shows that organizations in our sample are rather large with an average membership base of over 1000 farmers. Again, there is substantial inter-country variation since Malagasy organizations and, to a lesser extent, Rwandan organizations are much smaller than those in Kenya and Uganda. Because they combine scant managerial capital with the ambition to cater for large memberships, the organizations in our sample are likely to face significant crowding-in effects (or diseconomies of scale). These negative effects are, however, expected to be less important in Rwanda where the average organization has more managerial capacity and less members and is therefore more likely to sustain business operations during the COVID-19 crisis.

Table 4. Membership size of farmer-owned organizations.

\begin{tabular}{cccc}
\hline Number of Members Per Organization: & Obs. & Mean (Std. Dev.) & Min/Max \\
\hline Uganda & 96 & $1838(3092)$ & $15 / 13000$ \\
Malawi & 92 & $1166(2723)$ & $12 / 13350$ \\
Madagascar & 104 & $60.8(135.8)$ & $7 / 1220$ \\
Rwanda & 97 & $528.9(833.6)$ & $15 / 3671$ \\
Kenya & 54 & $2498(6735)$ & $15 / 45000$ \\
All countries & 443 & $1068(3110)$ & $7 / 45000$ \\
\hline
\end{tabular}

Source: Authors' computation based on survey data.

Overall, the descriptive analysis of the pre-COVID organizational data suggests that the resilience of sampled organizations to a systemic shock may be relatively low on average due to their young age or organizational immaturity, limited business-orientation and limited managerial capacity relative to the size of their membership base. However, considerable heterogeneity in all these indicators suggests that some organizations and especially those based in Rwanda may fare better during the COVID-19 crisis than others. 
In what follows, we use qualitative data collected during the initial phase of the COVID19 crisis to further describe the actual challenges and changes implemented by some farmer-owned organizations in our sample.

\section{Rapid Appraisal during COVID}

Almost one year into the pandemic, the number of COVID-19 infections reported from Africa appears to remain relatively low. In most African countries, bold containment measures were taken as early as March 2020. These measures usually involved the declaration of a state of emergency associated with a curfew, the closing of airports and national and regional borders for people but not for goods as well as restrictions on internal transportation for people, the closing of schools, restaurants and bars and places of worship. Although the growth of new cases has somewhat slowed since July 2020 and a number of countries have cautiously eased some of their containment measures. However, domestic economies and schooling systems have not yet fully recovered given rise to public concerns [41,42].

To better understand how farmer-owned organizations fare during the COVID-19 crisis, we conducted a phone-based appraisal involving the leaders of 216 out of the 443 organizations in our sample in May 2020. (Kenyan organizations were omitted from this follow-up analysis because of the unfortunate overlapping of the COVID pandemic and a major locust outbreak, which made it impossible for us to discern the effect of the former systemic shock). The characteristics of this sample are summarized in Table 5. The appraisal involved the same leaders that participated in the CLLEs who were asked two open-ended questions: what is the effect of the COVID-crisis on your community? What role does your organization play in supporting member-households during this crisis?

Table 5. Sample of farmer-owned organizations from south-east Africa (during COVID).

\begin{tabular}{ccccc}
\hline Country & Baseline Survey & Follow-Up Survey & Sub-Regions & N. of Organizations \\
\hline Madagascar & February 2017 & May 2020 & 5 & 40 \\
Malawi & September 2016 & May 2020 & 3 & 78 \\
Rwanda & February 2018 & May 2020 & 5 & 42 \\
Uganda & May 2016 & May 2020 & 4 & 56 \\
Total & & & 216 \\
\hline
\end{tabular}

Source: Authors' computation based on survey data.

\subsection{The Effect of the COVID-Crisis on Rural Communities}

In Madagascar, even rural communities with zero cases of COVID-19 were said to be affected by social distancing measures. Because farmers could not use exchange labor on their fields, harvesting activities had to often be delayed. Where health barriers had been erected, buyers of agricultural products faced difficulties in reaching rural villages and producers could not sell their surplus. If buyers did manage to get to rural villages, the price offered for agricultural produce was said to be significantly lower than before the pandemic. In particular, the closure of COTONA, a big exporter and major buyer of vanilla, contributed to a sudden reduction in income-generating opportunities for many farm households. Due to a lack of means of public transport, several producers would travel to markets on foot to sell their produce or procure food. Some producers, who had to stock their harvest or personally carry it to local markets also experienced a higher level of insecurity and reported increased theft especially of fresh vanilla. Finally, the suspension of non-farm activities in the informal sector contributed to a fall in income for many farm households.

In Malawi, the marketing of agricultural produce had also become a problem for most rural communities. Here, respondents declared that the price paid by buyers for agricultural produce had fallen significantly. Larger buyers, such as the National Smallholder Farmers' Association of Malawi (NASFAM) and the government had stopped buying the surplus produced by farmer-owned organizations. Related loss in revenue had affected the ability of some farmers to buy inputs for the upcoming cropping season (from May to July). Theft of agricultural produce had also increased forcing some farmers to harvest prematurely. Options 
for piece-rate-work, such as day labor on farms, had all but disappeared. Because food-forwork community programs were also suspended, rural households struggled with increased unemployment and food expenses. An increase in the price of basic necessities had made it difficult for households to afford the same food basket as before the pandemic. Fear and stigmatization were often mentioned by leaders of farmer-owned organizations in Malawi, recalling the country's experience with the HIV epidemic. People with jobs that involved travel were often forced to self-isolate upon return.

In Rwanda, home confinement meant that jobs that required work outside the farmsuch as transporting of food and persons by motorcycle or bicycle or day laboring on other farmers' fields were lost. Additionally, due to the closure of markets, people were not able to buy further afield where prices were lower and food shopping had thus become more expensive. Farmers were struggling to attend to their crops due to restrictions on movement and no longer relied on their day laborers who could not travel to work the fields. Because of the closing of markets and reduced mobility, farmers could not take their produce to the market and experienced a loss in income. The same was noted for fishermen who continued to fish but were unable to sell their produce due to the closing of markets.

In Uganda, smallholders involved in cropping and gardening were able to continue their activities and were able to attend to their fields and gardens. With children no longer in school, more family labor was available and quite a few households had managed to plant more acreage in this period than normal, expecting a good harvest for the upcoming season as a result. Access to rural trading centers had however become a major problem due to restricted movement. Some markets were said to have closed and inputs had become more expensive. For those raising livestock, mainly pigs and poultry, accessing feed was particularly problematic due to an increase in transport costs. Additionally, respondents indicated that buyers in the village offered lower prices for farm produce compared to before the pandemic. Transport of produce for processing, e.g., rice to the mill, also appeared to be problematic. In rural areas, increased scarcity of necessities such as soap, sugar and salt had driven up prices while in urban areas the price of beans and maize flour had almost doubled. Many leaders of farmer-owned organizations mentioned struggling with these higher prices and with more mouths to feed due to school children and urban workers having returned home. Additionally, quite a few households were unable to complement their income from farming with informal and casual jobs such as transporting goods and people or shop-keeping.

\subsection{The Role of Farmer-Owned Organizations during the COVID-Crisis}

Farmer-owned organizations adapted to the COVID-pandemic in various ways. In Madagascar, some organizations allowed for side-selling or for their members to sell their produce independently to available buyers. This strategy was justified by a sudden reduction in the number of buyers that used to procure agricultural commodities in bulk. In a few cases, members were also allowed to withdraw funds from the communal saving schemes and financial reserves managed by their organizations. Although these side-selling and liquidation strategies allowed farm-households to cope with sudden loss of income, they de-facto entailed the dissolution of collective agribusiness. As a result, quite a few farmer-owned organizations focused on advocacy activities in an attempt to reach out to the government and aid organizations and obtain food or cash transfers or other forms of assistance. Some organizations had also distributed distillation equipment to members for them to produce herbal tonics and essential oils claimed to have anti-viral or immunityboosting properties. Others had started to train members on beekeeping, horticulture and jam-making so that farm-households would be able to satisfy their own and diverse dietary needs in the eventuality of a prolonged crisis. Only a few and particularly entrepreneurial organizations had proposed to use local warehouses to stock rice and maize so that these could be sold at a higher price after the crisis.

In Malawi, rural collective action and especially the aggregation and commercialization of agricultural produce seemed to have widely stalled during the crisis. The marketing 
committees of several farmer-owned organizations were however seeking out market outlets that could offer reasonable prices for agricultural output. For non-perishable produce, rural leaders had advised farmers to store their produce and sell at a later date. A few organizations also initiated bulking and storage of agricultural produce. A couple of others offered emergency loans, using communal savings and financial reserves, to members that were facing serious challenges in meeting their food needs during this period.

In Rwanda, quite a few farmer-owned organizations ceased all activities because social distancing measures implied that meetings could not be held and decisions not made. In several organizations, members were allowed to withdraw their savings and shares to cope with the sudden decrease in household income. Some organizations did provide market information and undertook efforts to connect with output buyers and input suppliers. However, only in a few cases did these organizations manage to continue bulking and marketing the agricultural produce of members.

Most farmer-owned organizations in Uganda indicated to have suspended their marketing services due to movement restrictions and an extended curfew. Quite a few organizations seemed to have entered a dormant state because the banning of gatherings meant that decisions could not be made. Several organizations provided extension services or gave out market information to farmers either on an individual basis by phone or by using free radio air-time. Some had found alternative ways to deal with social distancing measures and the need for inputs. One organization was asking farmers to order seed and chemicals by phone. These were then delivered by the technical staff using a motorcycle. Many were engaged in lobbying for financial support from the government or aid organizations.

Overall, farmer-owned organizations seemed to struggle and scramble during the first and most acute phase of the COVID-19 crisis. In particular, social distancing measures made it difficult for rural leaders to reach out to their members. The banning of meetings has meant that members could not cast their vote and that the quorum required to come to a decision could thus not be reached. None of the surveyed organizations have been able to organize a general meeting on-line. Several organizations also allowed their members to side-sell or withdraw their savings. Such a strategy ensured immediate relief for farm households to the detriment of agribusiness development and income-generation. It thus appears that many organizations were dissolving or sliding into a state of dormancy. Only a few organizations displayed some resilience and were able to adapt to the shock or even exploit new opportunities. For example, some organizations, especially in Rwanda, had successfully taken up or centralized the bulking, storing and marketing of agricultural output, or the distribution of inputs, so as to reduce the number of transactions carried out by their members as well as the crowding of local markets. Others, especially in Uganda, had started to provide their members with extension services and market information by phone or through the radio.

\section{Conclusions and Implications}

In this study, we used pre- and during-shock data on farmer-owned organizations operating in Southeast Africa to better understand whether and how these can help rural smallholders cope with the systemic shock induced by the COVID-19 pandemic. The qualitative data that we were able to gather at the peak of the pandemic, in May 2020, reveal that the health hazard was generally modest but that the effect of social distancing measures, closing of markets and reduced mobility was felt across the board. Many organizations entered a state of dormancy or even opted for corrosive adaptation strategies that allowed members to side-sell their produce or withdraw their shares. As such, the COVID-19 crisis has often undermined collective action creating a situation of arrested agricultural growth. One reason for this sudden drop in rural cooperation is that decisionmaking was heavily affected by the banning of gatherings. A few organizations devised innovative solutions to preserve the market linkages of rural smallholders such as the provision of extension services and market information by phone or the bulking and storing of agricultural surplus. Our findings suggest that the lack of resilience demonstrated by 
most cooperatives is associated with organizational immaturity, large membership size, elite capture and limited business-orientation resulting from a general lack of managerial capital. In the absence of managerial capital, farmer-owned organizations were only able to rely on social capital, which was however hardly leveraged due to the imposition of social distancing measures.

The shadow that the COVID-19 crisis will cast over the global economy is likely to be long and African farm-households risk being further marginalized from food value chains and related income-generating opportunities. In terms of policy implications, social protection programs based on food or cash transfers have the potential to preserve rural livelihoods in the short term, but governments and donors need to acknowledge that the main effects of this crisis may entail the exacerbation of poverty and food insecurity over time. To stave off this dire and long-term outcome, policy-making efforts need to consolidate the role played by farmer-owned organizations - the most traditional and labor-intensive form of agribusiness in Africa-in domestic value chains. To strengthen the business operations of these organizations and mitigate the consequences of the economic recession on rural smallholders, the development of managerial capital-for example through the hiring of professional business-managers, the provision of management training to a diverse rural audience, and the digitization of meetings and operations-appears critical. Interventions aimed at building managerial capital have the potential to help these organizations centralize and digitize decision-making processes and the bulking, storing and marketing of members' produce. By doing so, governments and donors could help rural Africa bounce back before the systemic shock induced by the COVID-19 pandemic further expands and deepens the economic gap between this part of the world and the rest. However, it needs to be noted that the descriptive nature of this study and its limitations in establishing causal relationships call for further research into the impact of future interventions that will strive to build the managerial capital of farmer-owned organizations in Africa.

Author Contributions: Conceptualization, N.F. and F.W.; methodology, N.F.; validation, F.W.; formal analysis N.F.; investigation, D.B.N. and N.F.; resources, N.F.; data curation, N.F. and D.B.N.; writingoriginal draft preparation, N.F. and F.W.; writing-review and editing, F.W.; project administration, N.F. and D.B.N.; funding acquisition, N.F. All authors have read and agreed to the published version of the manuscript.

Funding: This research was funded by OCDC (using multiple grants received by USAID's Cooperative Development Program), as well as by CTA (using multiple grants received from DEVCO-EU) and CIAT (using multiple numbers received by the CGIAR and its donors).

Institutional Review Board Statement: Not applicable.

Informed Consent Statement: Informed consent was obtained from all subjects involved in the study.

Data Availability Statement: Data available in a publicly accessible repository. The data presented in this study are openly available at www.edc.coop.

Conflicts of Interest: The authors declare no conflict of interest.

\section{References}

1. De La Fuente, A.; Jacoby, H.G.; Lawin, K.G. Impact of the West African Ebola Epidemic on Agricultural Production and Rural Welfare: Evidence from Liberia. J. Afr. Econ. 2020, 29, 454-474. [CrossRef]

2. Laborde Debucquet, D.; Will, M.; Swinnen, J.; Vos, R. COVID-19 risks to global food security. Science 2020, 369, 500-502. [CrossRef] [PubMed]

3. Resnick, D. COVID-19 lockdowns threaten Africa's vital informal urban food trade. In COVID-19 and Global Food Security; Swinnen, J., McDermott, J., Eds.; IFPRI: Washington, DC, USA, 2020. [CrossRef]

4. Ratner, B.D.; Meinzen-Dick, R.; May, C.; Haglund, E. Resource conflict, collective action, and resilience: An analytical framework. Int. J. Commons 2013, 7, 183-208. [CrossRef]

5. Roelants, B.; Dovgan, D.; Eum, H.; Terrasi, E. The Resilience of the Cooperative Model; CECOP-CICOPA: Brussels, Belgium, 2012.

6. Birchall, J.; Ketilson, L. Resilience of the Cooperative Business Model in Times of Crisis; ILO: Geneva, Switzerland, 2009. 
7. $\quad$ Bizikova, L.; Nkonya, E.; Minah, M.; Hanisch, M.; Rao Turaga, R.M.; Speranza, C.I.; Karthikeyan, M.; Tang, L.; Ghezzi-Kopel, K.; Kelly, J.; et al. A scoping review of the contributions of farmers' organizations to smallholder agriculture. Nat. Food 2020, 1, 620-630. [CrossRef]

8. Borzaga, C.; Galera, G.; Bodini, R.; Abate, G.T.; Dossa, Z.; Francesconi, G.N.; Ochanda, R.M. The Potential of the Social Economy for Local Development in Africa: An Exploratory Report; European Commission: Brussels, Belgium, 2014.

9. Wanyama, F.; Poulton, C.; Markelova, H.; Dutilly, C.; Bijman, J.; Francesconi, G.N.; Bernard, T.; Cook, M.; Badiane, O.; Wouterse, F. Collective Action among African Smallholders: Trends and Lessons for Future Development Strategies; IFPRI WCAO Thematic Research Note No. 5; IFPRI: Washington, DC, USA, 2014.

10. Wanyama, F.; Develtere, P.; Pollet, I. Reinventing the Wheel? African Cooperatives in a Liberalized Economic Environment; ILO Working Paper; University of Leuven: Leuven, Belgium, 2008.

11. Bernard, T.; Abate, G.T.; Abate, L.S. Agricultural Cooperatives in Ethiopia: Results of the 2012 ATA Baseline Survey; International Food Policy Research Institute: Washington, DC, USA, 2013. [CrossRef]

12. Mukarugwiza, E. The Hope for Rural Transformation: A rejuvenating Cooperative Movement in Rwanda; CoopAFRICA Working Paper No.12; ILO: Geneva, Switzerland, 2010.

13. Bernard, T.; Spielman, D.J.; Tafesse, A.S.; Gabre-Madhin, E.Z. Cooperatives for Staple Crop Marketing: Evidence from Ethiopia; International Food Policy Research Institute: Washington, DC, USA, 2010.

14. Bernard, T.; Collion, M.H.; De Janvry, A.; Rondot, P. Do village organizations make a difference in African rural development? A study for Senegal and Burkina Faso. World Dev. 2008, 36, 2188-2204. [CrossRef]

15. Hill, R.; Bernard, T.; Dewina, R. Cooperative Behaviour in Rural Uganda: Evidence from the Uganda National Household Survey; IFPRI Project Report 2008; IFPRI: Washington, DC, USA, 2008.

16. World Bank. World Development Report 2008: Agriculture for Development; Oxford University Press: New York, NY, USA, 2007.

17. Meador, J.E.; O’Brien, D. Placing Rwanda's agriculture boom: Trust, women empowerment and policy impact in maize agricultural cooperatives. Food Secur. 2019, 11, 869-880. [CrossRef]

18. Murphy, B.L. Locating social capital in resilient community level emergency management. Nat. Hazards 2007, 41, 297-315. [CrossRef]

19. Tadesse, G.; Abate, G.T.; Ergano, K. The Boundary of Smallholder Producers' Cooperatives: A Conceptual and Empirical Analysis. J. Agric. Econ. 2019, 70, 529-549. [CrossRef]

20. Francesconi, G.N.; Wouterse, F. Building the Managerial Capital of Agricultural Cooperatives in Africa. Ann. Public Coop. Econ. 2019, 90, 141-159. [CrossRef]

21. Francesconi, G.N.; Wouterse, F. The Health of Farmer-Based Organizations in Ghana: Organizational Diagnostics and Governance Implications. J. Dev. Stud. 2015, 51, 262-273.

22. Francesconi, G.N.; Wouterse, F. Promoting the Role of Farmer-Based Organizations for Value Chain Integration: The Tension between a Program's Targeting and an Organization's Investment Strategy. Agric. Econ. 2015, 46, 527-536. [CrossRef]

23. Francesconi, G.N.; Ruben, R. Fair Trade's theory of change: An evaluation based on the cooperative life cycle framework and mixed methods. J. Dev. Eff. 2014, 6, 268-283. [CrossRef]

24. Francesconi, G.N.; Heerink, N. Ethiopian agricultural cooperatives in an era of global commodity exchange: Does organizational form matter? J. Afr. Econ. 2010, 20, 153-172. [CrossRef]

25. Bernard, T.; Taffesse, A.S.; Gabre-Madhin, E.Z. The impact of cooperatives on smallholders' commercialization behaviour: Evidence from Ethiopia. Agric. Econ. 2008, 39, 147-161. [CrossRef]

26. Buell, R. The Native Problem in Africa; Frank Cass: London, UK, 1928.

27. Platteau, J.P. Is Culture an Obstacle to African Economic Development? Paper presented at IERC Conference; University of Southern California: Los Angeles, CA, USA, 2007.

28. Strickland, C.F. Co-Operation for Africa; Oxford University Press: London, UK, 1933.

29. Francesconi, G.N.; Ayerakwa, H.M. West African Grain Banks in a New Era of Food Crisis: A Policy Report; IFPRI: Washington, DC, USA; BMZ: Berlin, Germany; WFP: Rome, Italy, 2011.

30. Salifu, A.; Francesconi, G.N.; Kolavalli, S. A Review of Collective Action in Rural Ghana; IFPRI Discussion Paper 00998; IFPRI: Washington, DC, USA, 2010.

31. Chaddad, F.; Cook, M.L. Agro-industrialization of the global food economy: Bridging development economics and agribusiness research. Agric. Econ. 2000, 23, 207-218.

32. Oakeshott, R. The Case for Workers' Cooperatives; Routledge and Kegan Paul: London, UK, 1978.

33. Staatz, J.M. Farmers' incentives to take collective action via cooperatives: A transaction costs approach. In Cooperative Theory: New Approaches; Royer, J., Ed.; ACS Service Report; USDA: Washington, DC, USA, 1987; pp. 87-107.

34. Sexton, R.; Iskow, J. Factors Critical to the Success or Failure of Emerging Agricultural Cooperatives; Giannini Foundation Information Series no. 88-83; University of California: Davis, CA, USA, 1988.

35. Bruhn, M.; Karlan, D.; Schoar, A. What capital is missing in developing countries? Am. Econ. Rev. 2010, 100, 629-633. [CrossRef]

36. Bruhn, M.; Karlan, D.; Schoar, A. The impact of consulting services on small and medium enterprises: Evidence from a randomized trial in Mexico. J. Polit. Econ. 2018, 126, 635-687. [CrossRef]

37. Cook, M.L. A Life Cycle Explanation of Cooperative Longevity. Sustainability 2018, 10, 1586. [CrossRef]

38. Peterson, H.C.; Anderson, B.L. Cooperative strategy: Theory and practice. Agribus. Int. J. 1996, 12, 371-383. [CrossRef] 
39. Bijman, J.; Iliopoulos, C.; Poppe, K.J.; Gijselinckx, C.; Hagedorn, K.; Hanisch, M.; Hendrikse, G.W.J.; Kühl, R.; Ollila, P.; Pyykkönen, P.; et al. Support for Farmers' Cooperatives: Final Report; European Commission: Brussels, Belgium, 2012.

40. Bijman, J.; Hanisch, M.; van der Sangen, G. Shifting control? The changes of internal governance in agricultural cooperatives in the EU. Ann. Public Coop. Econ. 2014, 85, 641-661. [CrossRef]

41. IMF. Regional Economic Outlook for Sub-Saharan Africa; IMF: Washington, DC, USA, 2020.

42. IMF. Policy Responses to COVID-19; IMF: Washington, DC, USA, 2020. 